\title{
Discrimination the accessions of grapevine cultivars Taferyalt with phyllometric parameters
} El Oualkadi A*, Hajjaj B*

\author{
*INRA- Regional Agricultural Research Center of Tangier, Morocco \\ Corresponding author. E-mail: ai.oualkadi@gmail.com
}

\begin{abstract}
The northwestern region of Morocco is rich in native vine cultivars where the problem of synonymy and homonymy is very common and causes the spread of varieties or the color of the fruits. The name of the grape cultivar Taferyalt has become inseparable from the name of the northwestern region where the cultivar is met under different names. In front of this situation, we tried to classify the accessions which have the same ampelographic character but with the different names (synonyms) or which showed several names which are given to the same variety (homonyms). The results of the phyllometric analyzes confirmed that these accessions are different.
\end{abstract}

Keywords - Taferylat cultivar, Phyllometric parameters, Morocco, synonymy, homonymy.

\section{INTRODUCTION}

Vitis vinifera $L$., the commonly cultivated grapevine, is one of the most widely grown fruit plants in the world [1]. It has subspecies with West Asiatic and European origins, and ranges from Central Asia to the Mediterranean Basin [2]. The cultivated grape $V$. vinifera subsp. sativa has played an important economic and cultural role throughout human history in different parts of the world. Researchers from East and West European countries initiated efforts to collect and preserve germplasm from a wide range of countries, including regions where autochthonous germplasm had not been investigated by genetic and ampelographic methods [3, 4]. Traditionally, morphological and agronomical characteristics have been the main criteria for differentiating grapevine cultivars, but it is well known that many of those characters are strongly influenced by environmental conditions. In grape, synonymies are very common [5, 6, 7, 8, 9] and convergences of names for distinct cultivars (homonyms) also occur because of some peculiar features of the varieties or because they grow in different regions [10]. That is a major problem in the management of grapevine germplasm collections $[11,12]$.

Ampelometric methods can also be a useful tool in cultivar identification, as they are less expensive, do not require special equipment and can give relevant results if managed properly and the resulting data are analyzed appropriately. Leaf descriptors have generally been used as effective tools for characterization of grapevine cultivars [13], [14], [15], [16], [17], [18], [19], [20]. Study of plant morphology, mainly leaves, buds, and cluster morphology (also called ampelography) until it is the last means of detecting vine cultivars [21]. This method is still used for identification [22], [23], [24] particularly during the collection of data plants in situ. Many ampelographic studies have been made of grapevine cultivars from all over the world, but only a few have described those of Algeria and Morocco [25], [26], [27], [28]. Recently, many of the Maghrebi cultivars have now been profiled by nuclear and chloroplast microsatellite analysis [29], [30], [31], [32], [33].

In Morocco, the grapevine is one of the oldest crops, it is known from the past important wine growing areas despite this decline, and viticulture occupies an important place in the Moroccan socio-economic fabric. Actually in Morocco the most modern area of grapevine sector was constituted only by foreign introduced grapevine but these plant need adaptation cultural, simultaneously this exist the old local type of grapevines but the most of them not express all their potential of production and offer consequently a weak yield because the plantation of theses local grapevine was without grafting. In spite of this situation, the old grapes of grapevine remain much appreciated by the Moroccan consumer and during our prospection [30], the farmers claimed to make it begin research of improvement and valorization on its old grapevines. In this study we try to identify the native cultivar Taferyalt by used the phyllometric parameters.

\section{MATERIAL AND METHODS}

Twelve trees of Taferyalt accessions were selected in these study and thirty leaves of each tree was used. Several studies show that this is a sufficiently large and representative number of samples [34], [35], [36], [37], 
[38], [39]. The leaves selected were between the 7th and 12 th nodes, counted from the base of the primary branch following the recommendations of the [40].The leaves were dried in herbarium. Indeed, the measurements were made on the sheets scanned using Super Ampelo software [41]. This software measures different quantitative characteristics of the sheet and also calculates different parameters such as distances, angles, ratios, and descriptors of the OIV (International Office of Vine and Wine) (Fig 1). The software provides a total of 125 numeric values for each sheet. But only 86 characters were used, eliminating redundancy between characters. Principal Component Analysis (A.C.P) was done using SPSS Version 10 software.
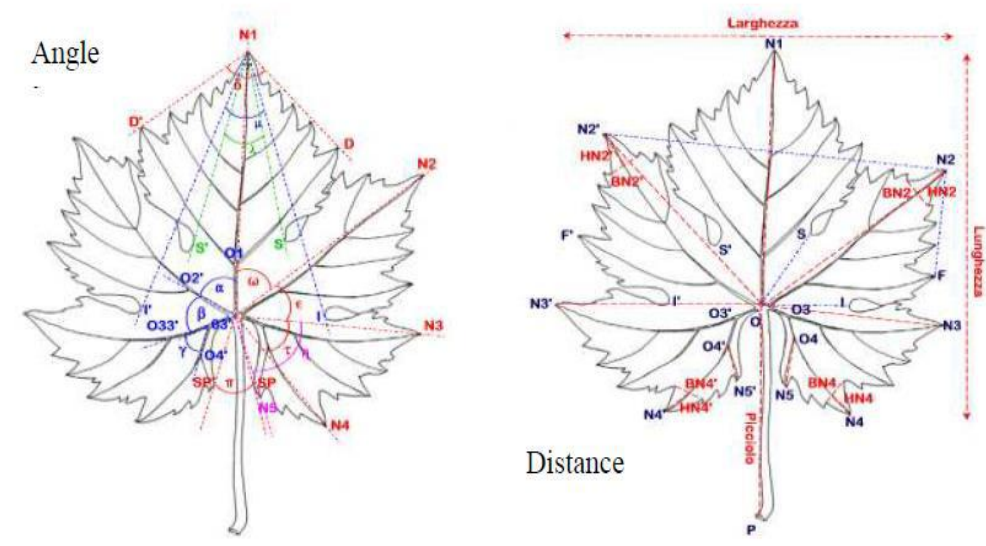

Fig.1. Point of the sheet requested by the information system to calculate the parameters (software Super Ampelo)

\section{RESULT AND DISCUSION}

The leaves of the vine represent five main veins. The relative dimensions of the nerves are certain elementary relations: wedge-shaped, cordate, pentagonal, circular and reniform. But the enormous variability of characters such as lobes, teeth, petiolar sinus, hairiness, pigmentation, are the rights of choice for the differentiation of varieties [42]. So, the shape of the leaf varies according to the varieties, it can also vary even on each foot. Indeed, it is not uncommon to see on one foot, leaves almost whole to another so cut up. The shape of the leaf is determined by the length of the nerves (NI, N2, N3, N4 and N5), as well as the angles between the veins $(\alpha, \beta, \varepsilon, \delta, \kappa, \mu)$. The size of the leaf is determined from its length (LU) and its width (LA). We distinguish a petiolar sinus (OP), an upper and lower lateral sinus, separating the lobes (Fig.1).

Average distances

We calculated the average for the leaf parameters of the different trees from the automatic measurements performed by the SuperAmpelo software (Table 1). Originally, the software measures 86 parameters for each leaf. This total number seems to be high compared to previous studies on grapevine cultivars as [43] (43 descriptors); [44] (50 descriptors); [45] (61 descriptors) and [46] (71 descriptors). We performed an analysis of variance to find the most discriminating parameters, we have shown that only 20 most discriminating parameters for distances and angles whereas only 16 parameters are the most discriminating for angles (Table 1, 2 and 3).

From Table 1 it can be seen that the tree Taferyalt khal 2 presents the means of the distances of the different points of the highest leaves compared to other trees of the Taferyalt variety. In general, and from the results of Table 1 we can say that the different tree of the variety Taferyalt does not represent the same average values of the different points of the leaves.

Table 1: Averages of the most discriminating parameters among the distances

\begin{tabular}{|c|c|c|c|c|c|c|c|c|c|c|c|c|c|c|c|c|c|c|c|c|}
\hline Tree & $\mathrm{OP}$ & OS & OS1 & OI & OI1 & HN2 & HN21 & HN4 & HN41 & $\mathrm{BN} 2$ & BN21 & $\mathrm{BN} 4$ & BN41 & OO31 & $\mathrm{OO} 3$ & SPSP1 & N4N41 & FN21 & O4N5 & O41N51 \\
\hline \multicolumn{21}{|c|}{ Aferyal khal } \\
\hline 1 & 18.39 & 12.38 & 11.13 & 12.4 & 11.07 & 1.92 & 1.79 & 2.04 & 1.75 & 3 & 2.55 & 2.96 & 2.77 & 2.71 & 4.57 & 24.11 & 17.85 & 12.93 & 4.76 & 2.61 \\
\hline \multicolumn{21}{|c|}{ Feryal khal } \\
\hline 2 & 14.17 & 14.61 & 13.86 & 13.84 & 12.93 & 3.48 & 2.38 & 3.16 & 2.69 & 3.88 & 3.31 & 3.95 & 3.35 & 4.25 & 5.82 & 28.95 & 26.19 & 15.83 & 5.69 & 4.10 \\
\hline Taferyalt & 16.14 & 11.75 & 11.18 & 11.57 & 10.48 & 2.03 & 1.86 & 2.12 & 1.85 & 2.91 & 2.39 & 2.69 & 2.28 & 2.46 & 4.22 & 23.59 & 15.61 & 12.05 & 4.36 & 2.47 \\
\hline
\end{tabular}




\begin{tabular}{|c|c|c|c|c|c|c|c|c|c|c|c|c|c|c|c|c|c|c|c|c|}
\hline Khal3 & & & & & & & & & & & & & & & & & & & & \\
\hline $\begin{array}{l}\text { Taferyalt } \\
\text { Khal } 4 \\
\text { Taferyalt }\end{array}$ & 16.92 & 11.8 & 10.87 & 11.68 & 10.91 & 1.79 & 1.65 & 1.93 & 1.63 & 2.86 & 2.5 & 2.78 & 2.39 & 2.52 & 4.35 & 23.62 & 17.11 & 11.69 & 4.29 & 2.14 \\
\hline $\begin{array}{l}\text { Kahla5 } \\
\text { Taferyalt }\end{array}$ & 14.61 & 10.08 & 9.261 & 10.31 & 8.93 & 1.87 & 1.65 & 1.91 & 1.56 & 2.73 & 2.38 & 2.86 & 2.24 & 2.09 & 4.16 & 19.9 & 10.62 & 10.16 & 4.28 & 1.83 \\
\hline $\begin{array}{l}\text { Kahla } \\
\text { Taferyalt }\end{array}$ & 24.06 & 13.29 & 12.46 & 12.38 & 12.48 & 2.11 & 2.27 & 2.57 & 2.54 & 2.81 & 2.69 & 2.91 & 3.11 & 2.65 & 6.1 & 26.25 & 19.49 & 14.64 & 7.18 & 2.03 \\
\hline $\begin{array}{l}\text { Kahla7 } \\
\text { Taferyalt }\end{array}$ & 23.73 & 11.3 & 10.4 & 11.06 & 9.754 & 2.03 & 2 & 2 & 1.95 & 2.78 & 2.68 & 2.79 & 3.12 & 2.59 & 5.54 & 24.33 & 16.13 & 13.5 & 5.73 & 2.10 \\
\hline $\begin{array}{l}\text { Kahla8 } \\
\text { Aferyal }\end{array}$ & 25.51 & 13.31 & 12.05 & 13.49 & 12.09 & 2.11 & 1.84 & 2.19 & 1.81 & 3.13 & 2.83 & 2.97 & 2.59 & 1.88 & 5.96 & 25.12 & 15.5 & 12.21 & 5.59 & 1.94 \\
\hline $\begin{array}{l}\text { Byad1 } \\
\text { Aferyal }\end{array}$ & 18.39 & 12.38 & 11.13 & 12.4 & 11.07 & 1.92 & 1.79 & 2.04 & 1.75 & 3 & 2.55 & 2.96 & 2.77 & 2.71 & 4.57 & 24.11 & 17.85 & 12.93 & 4.76 & 2.61 \\
\hline $\begin{array}{l}\text { Byad2 } \\
\text { Taferyalt }\end{array}$ & 14.07 & 12.88 & 12.38 & 12.87 & 12.33 & 2.64 & 2.13 & 2.76 & 1.98 & 2.76 & 3.39 & 2.88 & 3.31 & 2.77 & 7.13 & 25.82 & 16.47 & 15.44 & 7.52 & 2.83 \\
\hline $\begin{array}{l}\text { Byad3 } \\
\text { Taferyalt }\end{array}$ & 17.94 & 11.81 & 11.39 & 12.25 & 11.95 & 2.61 & 2.27 & 2.98 & 2.26 & 3.08 & 2.59 & 3.54 & 2.75 & 3.67 & 4.82 & 25.44 & 19.9 & 13.38 & 4.79 & 3.42 \\
\hline Byad4 & 17.47 & 12.97 & 13.16 & 12.62 & 11.99 & 2.78 & 2.18 & 2.62 & 2.13 & 3.33 & 2.82 & 3.09 & 2.71 & 3.55 & 4.74 & 25.34 & 21.31 & 14.23 & 4.87 & 3.59 \\
\hline
\end{tabular}

Average angles

The average values of the angles of the points of the different trees are very variable from one tree to another (Table 2). Note that the tree Aferyal bayad 2 shows the average values of the different points of very large angles compared to the average values of the angles of other trees.

Table 2: Averages of the most discriminating parameters among the angles

\begin{tabular}{|c|c|c|c|c|c|c|c|c|c|c|c|c|c|c|c|c|c|c|c|c|}
\hline Tree & $\begin{array}{l}\text { AL } \\
(\alpha)\end{array}$ & $\begin{array}{l}\mathrm{AL} 1 \\
\left(\alpha^{\prime}\right)\end{array}$ & $\begin{array}{l}\mathrm{BE} \\
(\beta)\end{array}$ & $\begin{array}{l}\text { BE1 } \\
\left(\beta^{\prime}\right)\end{array}$ & $\begin{array}{l}\text { GA } \\
(\gamma)\end{array}$ & $\begin{array}{r}(\mathrm{GA} 1 \\
\left(\gamma^{\prime}\right)\end{array}$ & $\begin{array}{l}\text { ET } \\
(\varepsilon)\end{array}$ & $\begin{array}{c}\text { ET1 } \\
\left(\varepsilon^{\prime}\right)\end{array}$ & TA & TA1 & $\begin{array}{l}\text { PI } \\
(\pi)\end{array}$ & $\begin{array}{l}\mathrm{DE} \\
(\delta)\end{array}$ & $\begin{array}{l}\text { LAM } \\
(\kappa)\end{array}$ & $\begin{array}{l}\mathrm{MU} \\
(\mu)\end{array}$ & $\begin{array}{c}\text { ALBE } \\
(\alpha+\beta) \\
(\mu)\end{array}$ & $\begin{array}{c}\text { ALBE1 } \\
\left(\alpha^{\prime}+\beta^{\prime}\right)\end{array}$ & $\begin{array}{c}\text { ALBEGA } \\
(\alpha+\beta+\gamma)\end{array}$ & $\begin{array}{c}\text { ALBEGA1 } \\
\left(\alpha^{\prime}+\beta^{\prime}+\gamma^{\prime}\right)\end{array}$ & $\begin{array}{l}\text { ANGA } \\
(\eta)\end{array}$ & $\begin{array}{c}\text { ANGA1 } \\
\left(\eta^{\prime}\right)\end{array}$ \\
\hline $\begin{array}{l}\text { Aferyal } \\
\text { khal } 1 \\
\text { Feryal khal }\end{array}$ & 50.76 & 55.59 & 48.73 & 11.07 & 50.78 & 50.54 & 47.2 & 48.45 & 42.6 & 42 & 59.14 & 113.8 & 45.45 & 49.15 & 99.48 & 66.67 & 150.3 & 117.2 & 59.07 & 58.54 \\
\hline $\begin{array}{l}2 \\
\text { Taferyalt }\end{array}$ & 51.55 & 54.38 & 45.32 & 10.81 & 51.89 & 55.79 & 44.3 & 49.3 & 41.6 & 41.9 & 69.12 & 103 & 41.3 & 48.42 & 96.85 & 65.2 & 148.8 & 121 & 59.17 & 60.07 \\
\hline $\begin{array}{l}\text { Khal3 } \\
\text { Taferyalt }\end{array}$ & 54.71 & 51.68 & 48.81 & 9.7 & 51.93 & 49.4 & 52.1 & 45.91 & 43.1 & 41.9 & 60.54 & 107.4 & 42.68 & 48.46 & 103.5 & 61.36 & 155.5 & 110.8 & 57.72 & 56.79 \\
\hline $\begin{array}{l}\text { Khal4 } \\
\text { Taferyalt }\end{array}$ & 47.88 & 47.06 & 45.43 & 8.64 & 49.24 & 48.83 & 51.7 & 44.6 & 40.5 & 41.6 & 73.22 & 108.3 & 40.13 & 49.19 & 93.33 & 55.7 & 142.5 & 104.5 & 55.78 & 55.35 \\
\hline $\begin{array}{l}\text { Kahla5 } \\
\text { Taferyalt }\end{array}$ & 54.29 & 56.68 & 50.5 & 11.48 & 56.4 & 59.06 & 52.9 & 50.81 & 48.1 & 50.1 & 36.23 & 108.2 & 44.83 & 46.65 & 104.8 & 68.16 & 161.2 & 127.2 & 65.91 & 68.56 \\
\hline $\begin{array}{l}\text { Kahla } \\
\text { Taferyalt }\end{array}$ & 51.56 & 55.93 & 43.51 & 11.56 & 54.16 & 52.95 & 44.2 & 45.59 & 45.4 & 46.9 & 35.75 & 98.71 & 42.43 & 50.06 & 95.05 & 67.49 & 149.2 & 120.4 & 73.73 & 69.64 \\
\hline $\begin{array}{l}\text { Kahla7 } \\
\text { Taferyalt }\end{array}$ & 51.48 & 51.27 & 46.45 & 10.92 & 53.27 & 54.29 & 47.8 & 50.22 & 46.8 & 48.1 & 41.94 & 105.2 & 36.03 & 43.32 & 97.93 & 62.19 & 151.2 & 116.5 & 68.15 & 68.48 \\
\hline $\begin{array}{l}\text { Kahla8 } \\
\text { Aferyal }\end{array}$ & 49.8 & 47.54 & 43.74 & 10.02 & 48.94 & 45.22 & 45.6 & 50.16 & 49.6 & 48 & 37.46 & 89.75 & 44.36 & 48.41 & 93.55 & 57.56 & 142.5 & 102.8 & 70.08 & 73.51 \\
\hline $\begin{array}{l}\text { Byad1 } \\
\text { Aferyal }\end{array}$ & 50.76 & 55.59 & 48.73 & 11.07 & 50.78 & 50.54 & 47.2 & 48.45 & 42.6 & 42 & 59.14 & 113.8 & 45.45 & 49.15 & 99.48 & 66.67 & 150.3 & 117.2 & 59.07 & 58.54 \\
\hline $\begin{array}{l}\text { Byad2 } \\
\text { Taferyalt }\end{array}$ & 56.33 & 75.96 & 58.85 & 17.74 & 57.84 & 56.44 & 51.1 & 53.83 & 48 & 49.2 & 17.58 & 109.9 & 45.81 & 47.57 & 115.2 & 93.69 & 173 & 150.1 & 74.87 & 73.89 \\
\hline $\begin{array}{l}\text { Byad3 } \\
\text { Taferyalt }\end{array}$ & 52.01 & 57.72 & 43.95 & 8.07 & 53.35 & 52.57 & 50.5 & 48.56 & 40.4 & 39.3 & 76.13 & 103.6 & 37.15 & 46.89 & 95.96 & 65.79 & 149.3 & 118.4 & 53.05 & 53.2 \\
\hline Byad4 & 56.35 & 54.11 & 44.62 & 7.53 & 51.75 & 53.06 & 49.5 & 45.08 & 39.8 & 39.8 & 74.15 & 105.9 & 44.55 & 51.01 & 100.9 & 61.65 & 152.7 & 114.7 & 54.38 & 56.54 \\
\hline
\end{tabular}

Average ratios

Table 3 shows the reports of different measurements made by the SuperAmpelo software. We note that the different rations are variable between the trees of the variety Taferyalt.

Table 3: Averages of the most discriminating parameters among the ratios

\begin{tabular}{|c|c|c|c|c|c|c|c|c|c|c|c|c|c|c|c|c|}
\hline Tree & RS & RS1 & HD & LULA & RI & HBD & HBD1 & HD1 & $\mathrm{RP}$ & RI1 & ALBEOSOI & ALBEOSOI1 & HBN2 & HBN41 & HBN21 & HBN4 \\
\hline Aferyal khal 1 & 0,52 & 0,51 & 1,23 & 0,91 & 0,62 & 0,66 & 1,32 & 2,50 & 0,73 & 0,61 & 0,08 & 0,05 & 0,67 & 0,64 & 0,71 & 0,70 \\
\hline $\begin{array}{l}\text { Feryal khal } 2 \\
\text { Taferyalt }\end{array}$ & 0,50 & 0,46 & 1,57 & 0,88 & 0,62 & 0,63 & 1,42 & 3,18 & 0,45 & 0,56 & 0,06 & 0,05 & 0,90 & 0,8 & 0,73 & 0,82 \\
\hline $\begin{array}{l}\text { Khal3 } \\
\text { Taferyalt }\end{array}$ & 0,49 & 0,50 & 1,27 & 0,95 & 0,65 & 0,71 & 1,54 & 2,43 & 0,63 & 0,64 & 0,09 & 0,05 & 0,71 & 0,86 & 0,76 & 0,81 \\
\hline Khal4 & 0,50 & 0,50 & 1,15 & 0,93 & 0,63 & 0,63 & 1,31 & 2,35 & 0,65 & 0,64 & 0,08 & 0,05 & 0,63 & 0,70 & 0,66 & 0,73 \\
\hline
\end{tabular}




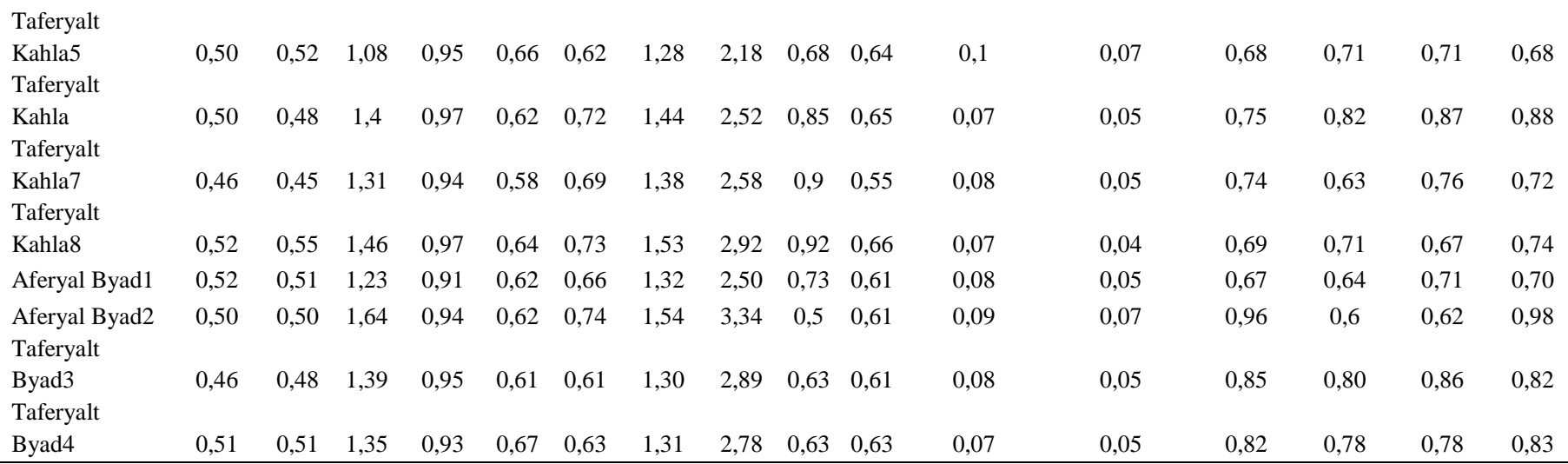

Principal component analysis

Using different leaf phyllometric measurements, we performed a principal component analysis of the different trees of the Taferyalt variety to see if the trees cluster together. The result is shown in Figure 2. From the figure we see that the trees of the taferylat variety form a group together except one tree Taferyalt Beyad 2 which is very far from other trees. Also the tree Taferyalt khal 1 and tree Taferyalt Byad 1 are superimposed. According to the result of the principal component analysis it can be said that it is a single vine variety Taferylat presented by several accessions, except the tree Taferyalt Beyad 2.

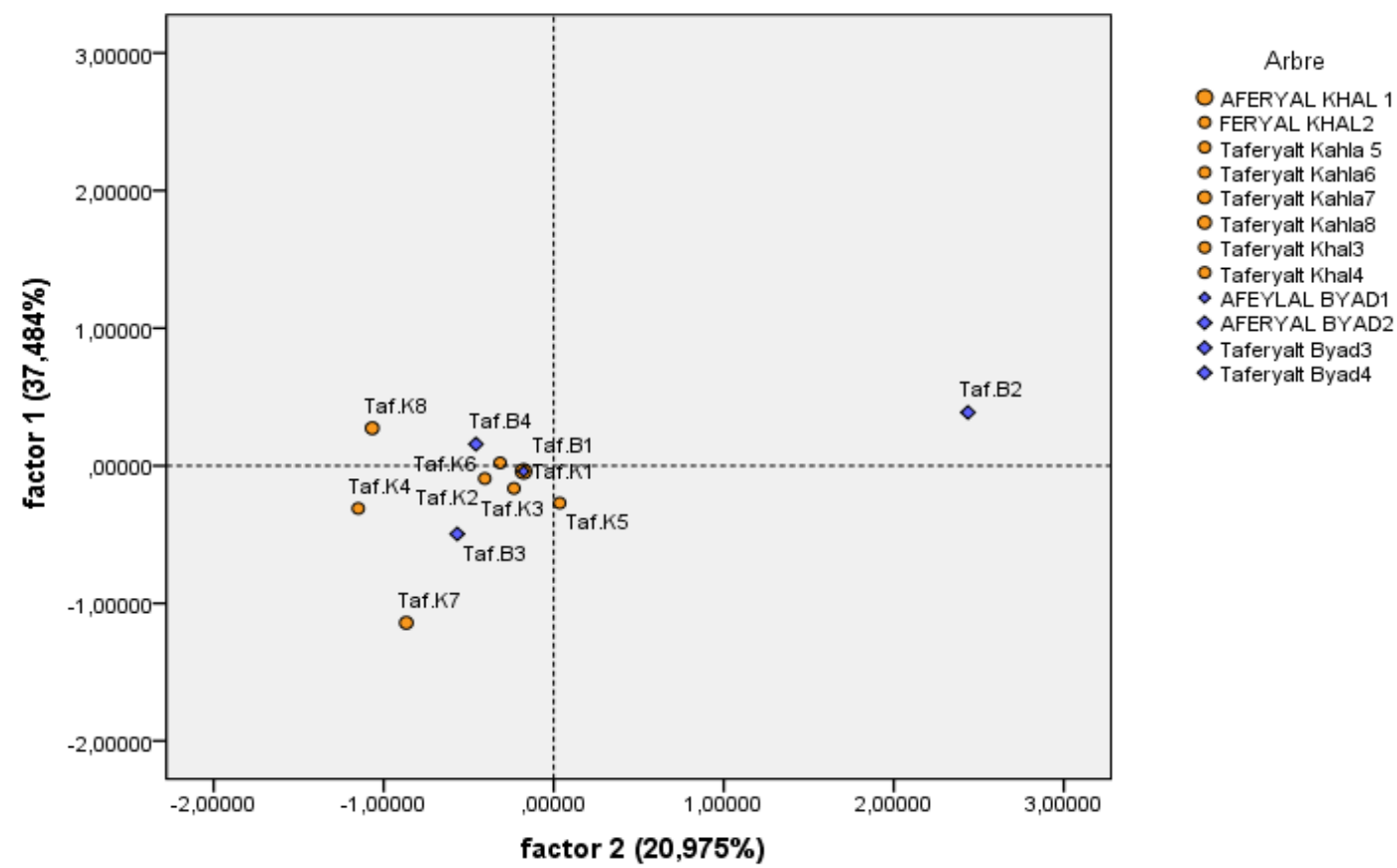

Fig. 2: Representation of the 12 trees of the "variety" Taferyalt

This result can be explained by the fact that there are problems of nomenclature due mainly to synonymy (several names are given to the same variety) and homonymy (the same name is given to several varieties). This problem is very common among local varieties. Synonymies are particularly related to the dissemination of varieties, which have been widely circulated and which have often been named differently in the different growing areas. As for the homonymy very common in the culture of the Moroccan vine, it is particularly determined by the color of the fruit as for the varieties "EL Biod and EL
Kehal". The names El Biod and El Kehal are given to varieties for which the morphological characters are different but whose fruits have a white or black color, hence the Arabic name of EL Biod (White) or EL Kehal (Black). In other study, [47] presumed the variety 'Kéknyelu"' for the same as the Italian 'Picoletto bianco' (= 'Picolit'). [48] commented that Italian ampelographers approve of the similarity of the two cultivars. He suggests importing 'Picolit' to Hungary to clarify this issue. Nowadays molecular markers are useful tools detect homonymies and synonymies [49]. 


\section{CONCLUSION}

In this study, the different parameters phyllometric was used to identifiy the accessions of one of the must answered cultivars in the north western of morocco, the result indicate the clear difference between the two studied accessions. On the basis of these results it can be established, that as we supposed the studied cultivars are different.

\section{REFERENCES}

[1] Vivier MA, Pretorius IS (2002) Genetically tailored grapevines for the wine industry. Trends Biotechnol. 20:472-8.

[2] Zohary D, Hopf M (2000) Domestication of plants in the old world. 3rd ed. New York: Oxford University Press.

[3] Failla O (2015) East-west collaboration for grapevine diversity exploration and mobilization of adaptive traits for breeding: a four years story. Vitis; 54:1-4.

[4] Maul E, Töpfer R, Carka F, Cornea V, Crespan M, Dallakyan M, et al (2015) Identification and characterization of grapevine genetic resources maintained in eastern European collections. Vitis. 54:5-12.

[5] Sefc KM, Lefort F, Grando MS et al (2001) Microsatellite markers for grapevine: a state of the art. In : RoubelakisAngelakis KA (ed.), Molecular biology \& biotechnology of grapevine, vol.1, Kluwer Academic Publishers, The Netherlands, Amsterdam: 407-438

[6] Riaz S, Dnagl GS, Edwards KJ et al (2004) A microsatellite marker based framework linkage map of Vitis vinifera $L$. Theor Appl Genet 108:864-872.

[7] Montaner C, Casanova J, Ortiz J.M et al (2004) Application of microsatellite markers for the characterization of 'Parraleta': an autochthonous Spanish grapevine cultivar. Sci Horti 101:343-347.

[8] Ortiz J.M, Martin J.P, Borrego J (2004) Molecular and morphological characterization of a Vitis gene bank for the establishment of a base collection. Genet Resour Crop Evol 51:403-409

[9] Walker M.A, Lowe K.M (2006) Genetic linkage map of the interspecific grape rootstock cross Ramsey (Vitis champinii) and Riparia Gloire (Vitis riparia). Theor Appl Genet 112:1582-92.

[10] This P, Lacombe T, Thomas MR (2006) Historical origin and genetic diversity of wine grapes. Trends Genet 424 22:511-519

[11] Lopes, M.S, Sefc, K.M, Eiras Dias E et al (1999) The use of microsatellites for germplasm management in a Portuguese grapevine collection. Theor Appl Genet 99:733-739

[12] Martin J.P, borrego J, Cabello F et al (2003) Characterization of Spanish grapevine cultivar diversity using sequence-tagged microsatellite site markers. Genome $46: 10-18$
[13] Tomažič, I.; Korošec-Koruza, Z (2003) Validity of phyllometric parameters used to differentiate local Vitis vinifera L. cultivars Enet. Resour. Crop Evol. 50, 773-778.

[14] Santiago, J.L., Bosso, S., Martín, J.P., Ortiz, J.M., Martínez, M.C (2005a) Characterization and identification of grapevine cultivars (Vitis vinifera L.) from northwestern Spain using microsatellites marker and ampelometric methods. Vitis 44, 67-72.

[15] Santiago, J.L., Boso, S., Martínez, M.C., Pinto-Carnide, O., Ortiz, J.M (2005b) Ampelographic comparison of grape cultivars (Vitis vinifera L.) grown in Northwestern Spain and Northern Portugal. Am. J. Enol. Vitic. 56, 288-290.

[16] Santiago, J.L., Boso, S., Gago, P., Alonso-Villaverde, V., Martinez, M.C (2007) Molecular and ampelographic characterisation of Vitis vinifera L. 'Albarino', 'Savagnin Blanc' and 'Caino Blanco' shows that they are different cultivars. Spanish J. Agricult. Res. 5, 333-340.

[17] Sabir, A., Tangolar, S., Buyukalaca, S., Kafkas, S (2009) Ampelographic and molecular diversity among grapevine (Vitis spp.) cultivars. Czech J. Genet. Plant Breed. 45, 160168.

[18] Gago, P., Santiago, J.L., Boso, S., Alonso-Villaverde, V., Grando, M.S., Martinez, M.C (2009) Biodiversity and characterization of twenty-two Vitis vinifera L. cultivars in the Northwestern Iberian Peninsula. Am. J. Enol. Vitic. 60, 293-301.

[19] Harbi-Ben Sliman, M., Snoussi, H., Bouhlal, R., Nahdi, H (2010) Ampelometry to test for genetic diversity in Tunisia Vitis sylvestris. Afr. J. Plant Sci. Biotechnol. 4, 17-22.

[20] Laiadi, Z., Bencharif, S., Lakhrif, Z., Bentchikou, M.M., Mohand-Larbi, R (2013) First ampelometric study of autochthonous grapevines in Algeria: germplasm collection of Mascara. Vitis 52, 21-27.

[21] Boursiquot JM, This P (1996) Les nouvelles techniques utilisées en ampélographie: Informatique et marquage. J Int Sci Vigne Vin Special issue: 12-23.

[22] Arrigo N. \& Arnold C (2007) Naturalised Vitis rootstocks in Europe and consequences to native wild grapevine. PlosOne 6, 521.

[23] Ortiz JM, Martin JP, Borrego J (2004) Molecular and morphological characterization of a Vitis gene bank for the establishment of a base collection. Genetic Resources and Crop Evolution 51: 403-409.

[24] Pavek DS, Lamboy WF et Garvey EJ (2003) Selecting in situ conservation sites for grape genetic resources in the USA. Genetics Ressources and Crop Evolution 50: 165173.

[25] Föex, G (1891) Cours complet de viticulture (Georges Masson Libraire Éditeur: Paris, France).

[26] Isnard, H (1951) La vigne en Algérie. Etude geographique (Ophrys: Gap, France).

[27] Vidal, J.P (1951) La vigne au Maroc (Terre Marocaine: Casablanca, Morocco).

[28] Levadoux, L., Benabderrabou, A. and Douaouri, B (1971) Ampélographie Algérienne: Cépages de cuve et de table cultivés en Algérie (SNED: Alger, Algeria). 
[29] El Oualkadi, A., Ater, M., Messaoudi, Z., Laucou, V., Boursiquot, J.M., Lacombe, T. and This, P (2009) Molecular characterization of Moroccan grapevine germplasm using SSR markers for the establishment of a reference collection. Journal International des Sciences de la Vigne et du Vin 43, 135-148.

[30] El Oualkadi, A., Ater, M., Messaoudi, Z., El Heit, K., Laucou, V., Boursiquot, J.M., Lacombe, T. and This, P (2011) Genetic diversity of Moroccan grape accessions conserved ex situ compared to Maghreb and European gene pools. Tree Genetics \& Genomes 7, 1287-1298.

[31] Laiadi, Z., Bentchikou, M.M., Bravo, G., Cabello, F. and Martinez-Zapater, J.M. (2009) Molecular identification and genetic relationships of Algerian grapevine cultivars maintained at the germplasm collection of Skikda (Algeria). Vitis 48, 25-32.

[32] Riahi, L., Zoghlami, N., El-Heit, K., Laucou, V., Le Cunff, L., Boursiquot, J.M., Lacombe, T., Mliki, A., Ghorbel, A. and This, P (2010) Genetic structure and differentiation among grapevines (Vitis vinifera) accessions from Maghreb region. Genetic Resources and Crop Evolution 57, 255272.

[33] Zinelabidine, L.H., Haddioui, A., Bravo, G., ArroyoGarcia, R. and Zapater, J.M.M. (2010) Genetic origins of cultivated and wild grapevines from Morocco. American Journal of Enology and Viticulture 61, 83-90

[34] Branas J (1974) Viticulture. Imp. Déhan, Montpellier. France

[35] Boursiquot J.M., Vignau L. et Boulet J.C (1989) Ricerche sull'utilizzazione dell'ampelometria. Riv. Vitic. Eno., 1, $37-52$.

[36] Detweiller E (1991) Preliminary minimal descriptor list of grapevine varieties. Institut fur Rebenz"uchtung Geilweilerhof. Siebeldingen. 12, pp. 10-17.

[37] Martinez M.C., Boursiquot J.M., Grenan S. et Boidron R (1997) Etude ampélométriques des feuilles adultes de somaclones de cv. De Grenache N. Can. Bot. 75: pp. 333345.

[38] OIV (2009) Office internationale de la vigne et du vin. Le code des caractères descriptifs des vari'et'es et espèces de Vitis.Ed. Dedon, Paris.

[39] Sefc K.M., Lefort F., Grando M.S., Scott K.D., Steinkellner H. and Thomas M.R (2001) Microsatellite markers for grapevine: a state of the art. In: Roubelakis-Angelakis K.A. (eds), molecular biology and biotechnology of grapevine, Kluwer Academic Publishers. Amsterdam. pp. 433-463.

[40] OIV (2009) Office internationale de la vigne et du vin. Le code des caractères descriptifs des variétés et espèces de Vitis.Ed. Dedon, Paris.

[41] Soldavini, C, Stefanini, M. Dallaserra, M. Policarpo, M. Schneider, A (2006) Superampelo, a software for ampelometric and ampelographic descriptions in Vitis. Acta Hortic. (ISHS) 827, 253-258.

[42] Huglin et Schneider (1998) Biologie et écologie de la vigne.
[43] Ekhvaia, J., Akhalkatsi, M (2010) Morphological variation and relationships of Georgian populations of Vitis vinifera L. subsp. sylvestris (C.C. Gmel.) Hegi. Flora 205, 608-617.

[44] Sladonja, B., Poljuha, D., Plavša, T., Peršurić, Đ., Crespan,M (2007) Autochthonous Croatian grapevine cultivar 'Jarbola' molecular, morphological and oenological characterization. Vitis 46, 99-100.

[45] Celik, H., Kose, B., Cangi, R (2008) Determination of fox grape genotypes (Vitis labrusca L.) grown in Northeastern Anatolia. Horticult. Sci. 35, 162-170.

[46] Lamine, M., Zemni, H., Ziadi, S., Chabaane, A., Melki, I., Mejri, S., Zoghlami, N (2014) Multivariate analysis and clustering reveal high morphological diversity in Tunisian autochthonous grapes (Vitis vinifera L.): insights into characterization, conservation and commercialization. J. Int. Sci. Vigne Vin 48, 111-122.

[47] Goethe, H., (1887) Handbuch der Ampelographie. Verlag Parey, Berlin.

[48] Németh, M., (1967) Ampelográfiai album I. (Termesztett borszo"lo"fajta'k 1.). Mezo"gazdasa'gi Kiado, Budapest.

[49] Ulanovsky, S., Gogorcena, Y., Martı'nez de Toda, F., Ortiz, J.M., (2002) Use of molecular markers in detection of synonymies and homonymies in grapevines (Vitis vinifera L.). Sci. Horticult. 92, 241-254. 